\title{
Use of an Excavation Compliance Indicator to Assess Conformance to Slope Design
}

\author{
J. Seery Rio Tinto Iron Ore, Pilbara Iron, Australia \\ J. Lapwood Rio Tinto Iron Ore, Pilbara Iron, Australia
}

\begin{abstract}
The compilation of factors associated with the construction of a slope has been collectively termed the excavation compliance indicator. The excavation compliance indicator is a tool that can be used to quantify the adherence to slope design in the operational mine environment. It is the collection of measurements pertaining directly to batter face angle and berm width and indirectly to the inter-ramp angle. The characteristics are measured from mine survey as-built pickups and Sirovision triangulations which have been imported into Maptek Vulcan. The characteristics are compared directly to the design batter face angle, berm width and inter-ramp angle.

To date, the excavation compliance indicator process has been undertaken on a number of pits in the West Pilbara Mine Operations at Pilbara Iron. The aim of undertaking this analysis is to assess the quality of excavation of slope angles and construction of berms to check conformance to design slope parameters.

In the analysis of mine survey as-built pickup data for the Tom Price South East Prongs pit, the as-built batter face angle was found to be on average 4 degrees lower than design batter face angle. It was found that in general, the average as-built batter face angle for the mine survey pickup was no more than 2 degrees lower than the interpreted Sirovision model batter face angle.
\end{abstract}

This work will help to drive the reconciliation process between the geotechnical design parameters and actual excavation performance. There is a direct correlation of the excavation compliance indicator to the drill and blast design and the final wall excavation process.

\section{Introduction}

The Geotechnical Considerations in Open Pit Mines Guidelines (Western Australian Government Department of Consumer and Employment Protection, 1999), states that prior to commencement of mining, an open pit excavation is required to have established an appropriate excavation design geometry. This analysis can be undertaken with reference to methods suggested in Hoek and Bray (1994), designing for planar, wedge and rock mass failure to obtain appropriate batter face angles, berm widths and hence inter ramp and overall wall angles.

Four papers have examined the process of assessment of probabilistic factors for the determination of slope angles including McMahon (1971), McMahon (1974), Morriss (1984) and Morriss and Stoter (1983). These papers do not address the implementation or conformance to design issues but do address the concepts of probability of failure for given slope angles. A number of papers have examined optimisation of design geometries based on geotechnical assessments (e.g. Bye and Bell, 2001; Singh et al. 2004; Singh and Singh, 1999; and Tsidzi, 1997) with publication of proposed slope angles. These papers have not undertaken any analysis for the conformance to the design parameters.

Four papers have examined the aspects associated with bench crest failure and back-break with no analysis of the aspects associated with the batter face angle. The papers include Alejano et al. (2007), Miller et al. (2000) and Whyatt et al. (2004).

The development of the excavation compliance indicator tool has assisted in quantifying the conformance to pit design. The indicator is the definition of the variability of the as-built batter face angle and the berm width to indicate the degree to which batters in a slope are either excavated shallower or steeper than the design batter face angle and the degree to which berms are excavated either narrower or wider than the 
design berm width. These two variables combine geometrically to produce an inter-ramp angle, with its variability defined by the variability of the batter face angle and berm width.

Pilbara Iron operates 33 active mining pits across the West Pilbara division. The case study presented here focuses on the South East Prongs pit at Tom Price Mining Area. The excavation compliance indicator tool has been used on six other pits in the West Pilbara division all exhibiting unique design parameters.

The excavation compliance indicator is a tool to be used in conjunction with a kinematic probabilistic analysis with respect to slopes where the potential for failure may be controlled by discontinuities. This tool is not intended to be used for analysis of slopes where the controlling failure mechanism is a large scale daylighting defect or rock mass failure. It is intended to highlight the implications of either increasing or decreasing the batter face angle and the berm width when compared to design. For example, increasing the batter face angle and the berm width in a kinematically designed slope may impact mine operations by increasing rockfall risk, although increasing instability in the batter face is countered by an increase in catch potential.

\section{Method}

To calculate the variability in batter face angle (BFA) and berm width (BW), a process has been developed whereby Maptek Vulcan is used to sample the batter face angle and berm width of a mine survey as-built pickup. An assessment is conducted of the slope aspect (i.e. the overall dip direction of the slope), and the slope divided into sectors based on slope aspect and/or design batter/berm design configuration. An assessment is also conducted on the bench height.

A baseline is created near the crest of a slope which has an average strike of the slope being assessed. Lines perpendicular to this baseline are extended over the slope in interest, with the perpendicular lines being spaced at the equivalent bench height of the slope being assessed. These lines are in effect created subparallel to the slope aspect.

Functionality in the Maptek Vulcan software allows the creation of points at the intersection of the lines and the mine survey as-built pickup. From here, the gradient of the batters and the width of berms can be digitised as a two point string for each batter and each berm. Digitised batters and berms are grouped according to their type.

Strings are exported for analysis in Microsoft Excel and are analysed according to the group they belong in (i.e. Batter or Berm). For batters, the gradient is calculated between the two string endpoints according to Equation 1.

$$
B F A=\cos ^{-1} \frac{\sqrt{\left(\Delta E^{2}+\Delta N^{2}\right)}}{\sqrt{\left(\Delta E^{2}+\Delta N^{2}+\Delta R L^{2}\right)}}
$$

where $\Delta \mathrm{E}, \Delta \mathrm{N}$ and $\Delta \mathrm{RL}$ is the difference in easting, northing and reduced level respectively between the two points of a digitised batter string. BFA represents the batter face angle.

For berms, the distance between the two string endpoints is calculated according to Equation 2.

$$
B W=\sqrt{\left(\Delta E^{2}+\Delta N^{2}+\Delta R L^{2}\right)}
$$

where $\Delta \mathrm{E}, \Delta \mathrm{N}$ and $\Delta \mathrm{RL}$ is the difference in easting, northing and reduced level respectively between the two points of a digitised berm string. BW represents the berm width.

For berm width, Microsoft Excel converts the arctangent of the two endpoints of the berm width midpoint calculations and aligns them with a clockwise angle from the y-axis of a Cartesian grid. This is represented by Equation 3.

$$
S A=(180-\operatorname{ATAN2}(\Delta E, \Delta N))
$$

where $\Delta \mathrm{E}, \Delta \mathrm{N}$ is the difference in easting and northing respectively between the two midpoints of a calculated berm width string. SA represents the berm width. 
These data are grouped and analysed according to the design sector being assessed.

Cumulative distribution curves are compiled for both the batter face angle and berm width and statistical analyses undertaken assuming that the data derived for batter face angle and berm width are normally distributed. Figure 1 shows the comparison of a hypothetical design batter face angle of $55^{\circ}$ (inferring no variation from the mean) compared to the representation of a hypothetical as-built batter face angle with a mean of $50^{\circ}$ and standard deviation of $2^{\circ}$. Thus, this particular example demonstrates the mean as-built batter face angle to be $5^{\circ}$ less than the design.

Elements of the Comparison of Actual versus Design Batter Face Angle

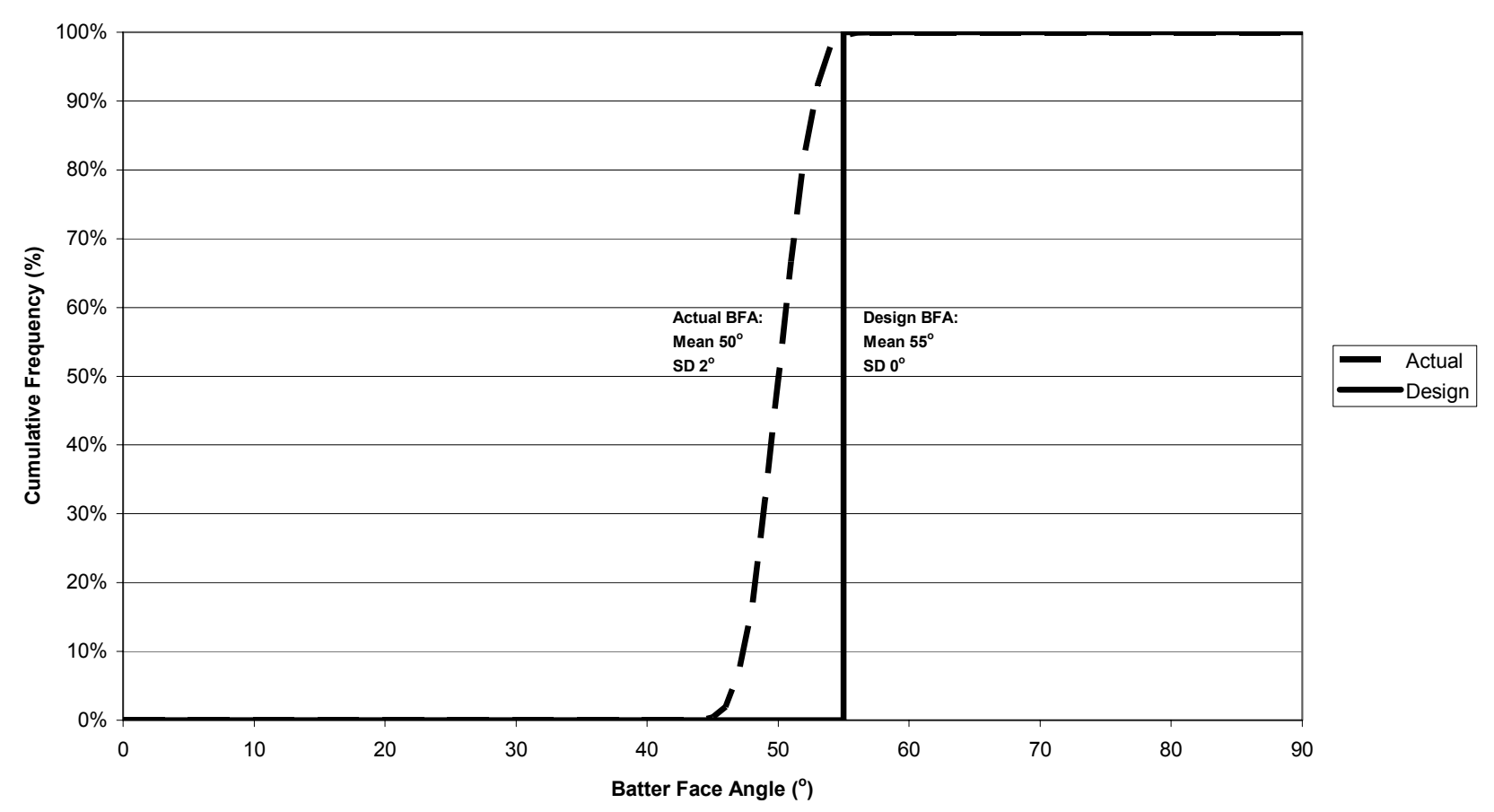

Figure 1 Elements of the comparison of as-built versus design batter face angle

\section{Data}

The South East Prongs pit has a planned depth of $375 \mathrm{~m}$ with walls designed against a kinematic assessment for a structurally controlled failure mechanism. The pit was divided into 19 sectors as defined by common berm width, batter face angle and berm width (and hence inter-ramp angle) geometries of the pit design. Figure 2 shows the layout of the Tom Price South East Prongs pit design with overlain sector analysis baselines and perpendicular lines. Analysis of the as-built batter face angle, berm width and berm width was undertaken against the mine survey as-built pickup data.

The 19 sectors were also analysed for batter face angle from Sirovision triangulation data to provide data on the topography of individual batters. The method of capture of the Sirovision triangulation data has meant that the topography of the berms has not been determined for these sectors. This is due to the angle of capture of the photographs from a level at the base of the slope, such that the berms are shadowed by the batter crest. 


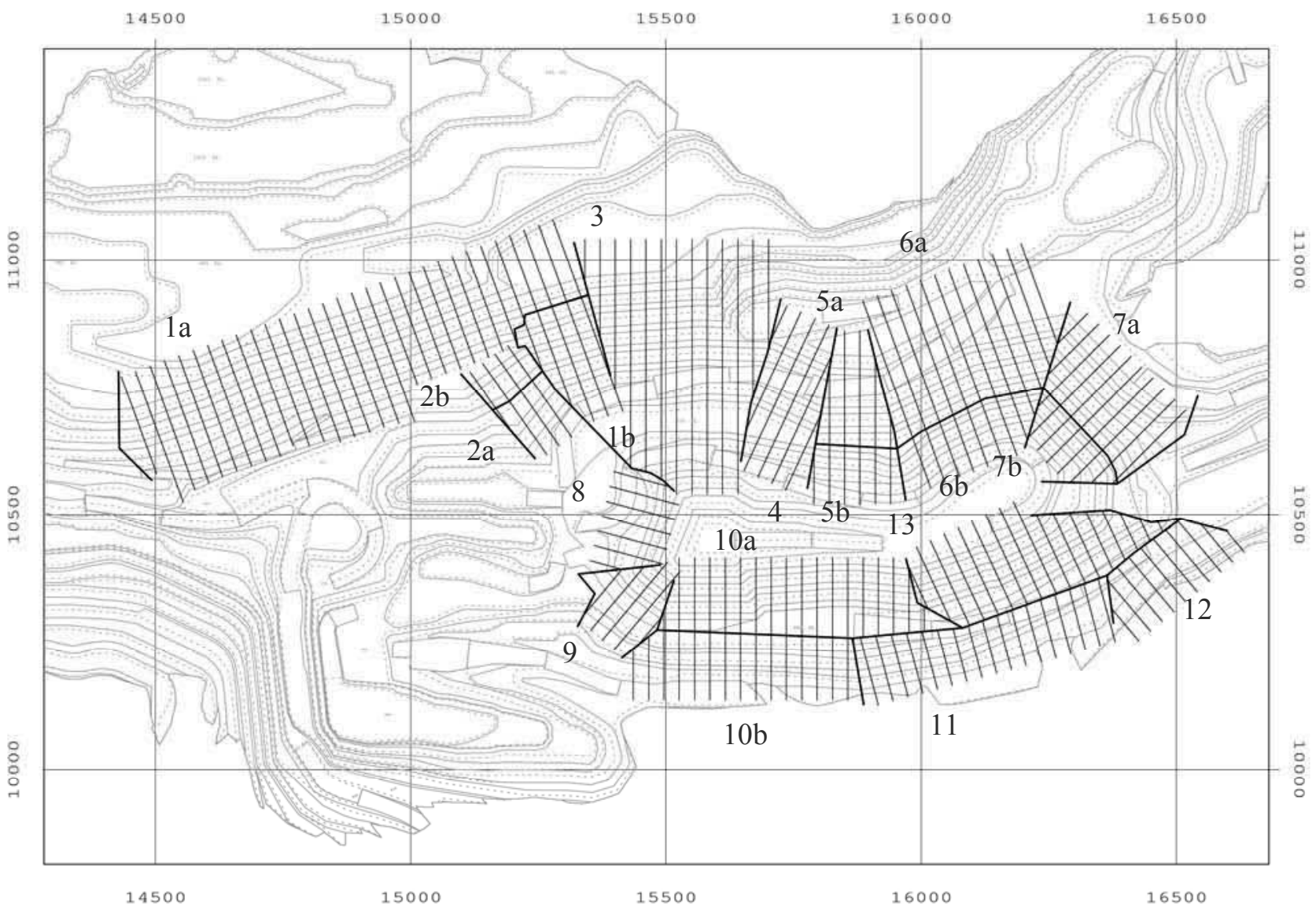

Figure 2 Overview of the South East Prongs portion of the Tom Price pit design, with perpendicular lines superimposed. Sectors numbered are reflected in Table 1

\section{$4 \quad$ Results}

The results of the analysis of excavation compliance indicator calculations on the South East Prongs pit walls can be summarised with an average as-built batter face angle generally $4^{\circ}$ less than the design batter face angle and the average as-built berm width generally $0.9 \mathrm{~m}$ less than the design berm width. These two factors combine to indicate an as-built inter-ramp angle of $2^{\circ}$ less than the design inter-ramp angle on average. The as-built berm width was found to conform to the design berm width. The mean as-built batter face angle was found to be on average $2^{\circ}$ less than the mean Sirovision derived batter face angle.

A summary of the key design versus as-built excavation compliance indicator factors for sectors defined in Figure 2 can be found in Table 1. 
Table 1 Summary of the key excavation compliance indicator factors

\begin{tabular}{|c|c|c|c|c|c|c|c|}
\hline Sector & $\begin{array}{c}\text { Design } \\
\text { batter face } \\
\text { angle } \\
\left(^{\circ}\right)\end{array}$ & $\begin{array}{l}\text { Mean as- } \\
\text { built batter } \\
\text { face angle } \\
\left(^{\circ}\right)\end{array}$ & $\begin{array}{c}\text { Mean } \\
\text { Sirovision } \\
\text { derived } \\
\text { batter face } \\
\text { angle }\left(^{\circ}\right)\end{array}$ & $\begin{array}{c}\text { Design } \\
\text { slope } \\
\text { aspect } \\
\left(^{\circ}\right)\end{array}$ & $\begin{array}{l}\text { Mean as- } \\
\text { built slope } \\
\text { aspect } \\
\left(^{\circ}\right)\end{array}$ & $\begin{array}{c}\text { Design } \\
\text { berm } \\
\text { width } \\
\text { (m) }\end{array}$ & $\begin{array}{l}\text { Mean as- } \\
\text { built berm } \\
\text { width } \\
\text { (m) }\end{array}$ \\
\hline $1 \mathrm{a}$ & 45 & 41 & 42 & 160 & 161 & 10.0 & 9.0 \\
\hline $1 b$ & 50 & 46 & 48 & 160 & 163 & 15.0 & 10.5 \\
\hline $2 a$ & 50 & 44 & 45 & 145 & 130 & 16.0 & 18.1 \\
\hline $2 b$ & 45 & 42 & 43 & 145 & 143 & 20.0 & 20.1 \\
\hline 3 & 50 & 46 & 47 & 180 & 178 & 10.0 & 10.2 \\
\hline 4 & 50 & 46 & 49 & 205 & 202 & 13.0 & 10.3 \\
\hline $5 a$ & 50 & 44 & 47 & 180 & 179 & 13.0 & 10.6 \\
\hline $5 b$ & 50 & 47 & 47 & 180 & 185 & 10.0 & 8.2 \\
\hline $6 a$ & 50 & 46 & 48 & 160 & 157 & 13.0 & 11.3 \\
\hline $6 \mathrm{~b}$ & 50 & 47 & 48 & 160 & 160 & 10.0 & 11.7 \\
\hline $7 \mathrm{a}$ & 50 & 43 & 44 & 225 & 227 & 13.0 & 10.2 \\
\hline $7 b$ & 50 & 47 & 46 & 225 & 228 & 10.0 & 9.9 \\
\hline 8 & 50 & 44 & 49 & 105 & 114 & Variable & 15.9 \\
\hline 9 & 50 & 49 & 52 & 040 & 039 & 10.0 & 6.7 \\
\hline $10 \mathrm{a}$ & 50 & 50 & 49 & 000 & 357 & 10.0 & 10.1 \\
\hline $10 \mathrm{~b}$ & 60 & 44 & 57 & 000 & 002 & 15.0 & 8.1 \\
\hline 11 & 50 & 40 & 46 & 345 & 344 & 8.0 & 10.8 \\
\hline 12 & 60 & 42 & 44 & 320 & 321 & 5.0 & 6.1 \\
\hline 13 & 50 & 46 & 47 & 335 & 335 & 10.0 & 9.0 \\
\hline
\end{tabular}

The best performance of batter face angle is seen in Sector 10a with a design and as-built batter face angle of $50^{\circ}$. The worst performance of batter face angle is seen in Sector $10 \mathrm{~b}$ with a design batter face angle of $60^{\circ}$ compared to the as-built batter face angle of $44^{\circ}$, a deviation of $16^{\circ}$. In terms of variability, the least variable batter face angle is seen in sector $1 \mathrm{~b}$ with a standard deviation of $1.81^{\circ}$. The most variable batter face angle slope is seen in sector $10 \mathrm{~b}$ with a standard deviation of $11.21^{\circ}$.

The best performance of berm width is seen in Sector 10a with a design berm width of $10 \mathrm{~m}$ and an as-built berm width of $10.1 \mathrm{~m}$. The worst performance of berm width is seen in Sector 10b with a design berm width of $15 \mathrm{~m}$ compared to the as-built berm width of $8.1 \mathrm{~m}$, representing a deviation of $6.9 \mathrm{~m}$. In terms of variability, the least variable berm width is in sector $1 \mathrm{~b}$ with a standard deviation of $1.73 \mathrm{~m}$. The most variable berm width is in sector 11 with a standard deviation of $6.97 \mathrm{~m}$. 
Table 2 Summary of the best and worst performing excavation compliance indicator factors

\begin{tabular}{|c|c|c|c|c|c|}
\hline \multirow[b]{2}{*}{$\begin{array}{l}\text { Batter face } \\
\text { angle }\end{array}$} & \multicolumn{3}{|l|}{ Mean } & \multicolumn{2}{|c|}{ Standard Deviation } \\
\hline & Sector & $\begin{array}{c}\text { As-built } \\
\text { batter face } \\
\text { angle }\left({ }^{\circ}\right)\end{array}$ & $\begin{array}{c}\text { Design batter } \\
\text { face angle } \\
\left({ }^{\circ}\right)\end{array}$ & Sector & $\begin{array}{c}\text { As-built } \\
\text { batter face } \\
\text { angle }\left({ }^{\circ}\right)\end{array}$ \\
\hline $\begin{array}{l}\text { Best } \\
\text { performance }\end{array}$ & $10 \mathrm{a}$ & 50 & 50 & $1 b$ & 1.81 \\
\hline $\begin{array}{l}\text { Worst } \\
\text { performance }\end{array}$ & $10 \mathrm{~b}$ & 44 & 60 & $10 \mathrm{~b}$ & 11.21 \\
\hline \multirow[b]{2}{*}{ Berm width } & \multicolumn{3}{|l|}{ Mean } & \multicolumn{2}{|c|}{ Standard Deviation } \\
\hline & Sector & $\begin{array}{l}\text { As-built } \\
\text { berm width } \\
\text { (m) }\end{array}$ & $\begin{array}{l}\text { Design berm } \\
\text { width } \\
\text { (m) }\end{array}$ & Sector & $\begin{array}{c}\text { As-built } \\
\text { berm width } \\
(\mathrm{m})\end{array}$ \\
\hline $\begin{array}{l}\text { Best } \\
\text { performance }\end{array}$ & $10 \mathrm{a}$ & 10.1 & 10 & $1 b$ & 1.73 \\
\hline $\begin{array}{l}\text { Worst } \\
\text { performance }\end{array}$ & $10 \mathrm{~b}$ & 8.1 & 15 & 11 & 6.97 \\
\hline
\end{tabular}

Further to this, the reconciliation of mine survey as-built data to Sirovision data indicates the Sirovision derived batter face angle data was on average $2^{\circ}$ higher than mine survey as-built batter face angle data. This indicates a generally good correlation between mine survey as-built procedures to actual topography of the batter face.

Figure 3 shows a cross-section through the pit profile in Sector 13. The figure shows the as-built mine survey batter cross-section and the Sirovision topography being in front of the mine design and at a shallower angle than the proposed design. The difference in the Sirovision and the mine survey reflects the resolution of the respective data acquisition methods, with (in this case) mine survey typically acquiring every $10 \mathrm{~m}$ along the toe and crest of batters and the Sirovision data acquiring points every $30 \mathrm{~cm}$.

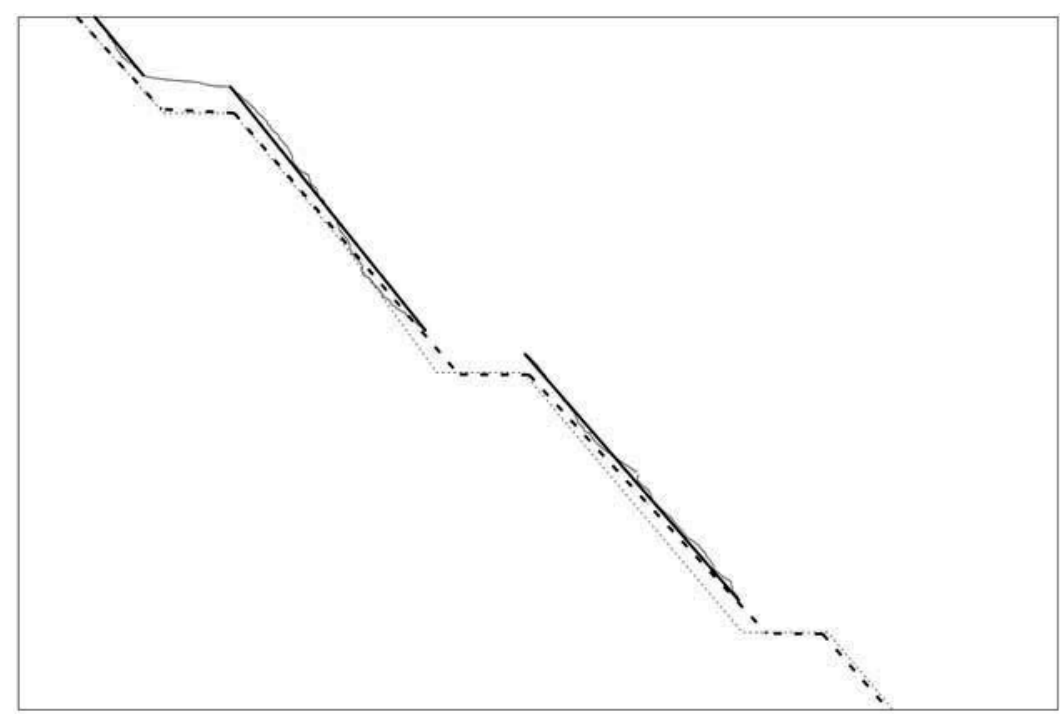

Figure 3 Detailed view of a cross-section through one section in sector 13. The thin dashed line represents the pit design and the thick dashed line represents the digitising of the mine survey as-built batter. The thin solid line represents the digitising of the Sirovision batter topography and the thick solid line represents the Sirovision derived batter face angle 


\section{Conclusions}

The excavation compliance indicator can be used as a tool for highlighting the reconciliation of design versus actual slope performance. As seen in this case study of the South East Prongs pit, the reconciliation between design and actual slope performance has shown no major deviations from design. This tool has been used to highlight conformance to design issues at six other pits in the West Pilbara Mine Operations and this will help to communicate implications of deviation from design.

Limitations of using the excavation compliance indicator include not using the tool in the context of kinematic analyses undertaken on the slope and the scale is limited to a bench height assuming a planar batter face geometry.

It is envisaged that the variability in the parameters of the batter face angle, berm width and berm width, combined with the variability of the dip of a kinematically controlling defect and the friction angle of that defect will contribute to the use of probability of failure calculations at Pilbara Iron.

Planned enhancements to the excavation compliance indicator tool include a mechanism for calculating the length of toe and crest in front of, behind or achieving design and quantifying the quality of the topography of batters. Work will also be undertaken to quantify the impacts on optimisation opportunities and ore reserve recoveries.

\section{References}

Alejano, L.R., Pons, B., Bastante, F.G., Alonso, E. and Stockhausen, H.W. (2007) Slope geometry design as a means for controlling rockfalls in quarries. International Journal of Rock Mechanics and Mining Sciences 44. Elsevier, pp. 903-921.

Bye, A.R. and Bell, F.G. (2001) Geotechnical applications in open pit mining. Geotechnical and Geological Engineering 19. Kluwer Academic Publishers. Netherlands, pp. 97-117.

Department of Consumer and Employment Protection (1999) Geotechnical considerations in open pit mines, guideline. http://www.docep.wa.gov.au/ResourceSafety/Mining_Safety/pdf_MS\%20GMP/Guidelines/MS_GMP_Guide_ geoconsguideopenpit.pdf, pp. 15-16.

Hoek, E. and Bray, J.W. (1994) Rock slope engineering. Revised third edition. Institution of Mining and Metallurgy, Melbourne.

McMahon, B. (1971) A statistical method for the design of rock slopes. Proceedings first Australia - New Zealand conference geomechanics, Melbourne, pp. 314-321.

McMahon, B. (1974) Design of rock slopes against sliding on pre-existing fractures. Proceedings 3rd Congress, Volume II Part B, International Society of Rock Mechanics, Denver, pp. 803-808.

Miller, S.M., Girard, J.M. and McHugh, E. (2000) Computer modelling of catch benches to mitigate rockfall hazards in open pit mines. Pacific Rocks 2000 (Proceedings 4th North American rock mechanics symposium), Girard, J., Liebman, M., Breeds, C. and Doe, T. (eds.), Balkema. Rotterdam, pp. 539-545.

Morriss, P. and Stoter, H.J. (1983) Open-cut slope design using probabilistic methods. 5th ISRM congress on rock mechanics, Section C. International Society of Rock Mechanics. Melbourne, pp. 107-113.

Morriss, P. (1984) Understanding and applying probabilistic concepts to rock slope design. 4th Australia - New Zealand conference on geomechanics, Perth, Western Australia. Institute of Engineers.

Singh, V.K., Singh, J.K. and Kumar, A. (2004) Geotechnical study and optimal design at Lakjura opencast coal mine, India. International Journal of Rock Mechanics and Mining Sciences. Elsevier.

Singh, V.K. and Singh, T.N. (1999) Geotechnical study of the optimum design of the Chandmari coppermine, Rajasthan, India. Engineering Geology 53 pp, 47-55. Elsevier Science.

Tsidzi, K.E.N. (1997) An engineering geological approach to road cutting slope design in Ghana. Geotechnical and Geological Engineering. Chapman and Hall.

Whyatt, J.K., MacLaughlin, M. and Miller, S. (2004) Analysis of bench crest performance at the Yellowstone Mine: A case study. Proceedings 39th symposium on engineering geology and geotechnical engineering: research to practice, McLaughlin, M. and McNearny, R. (eds.) Montana Tech of the University of Montana, pp. 149-163. 